\title{
Beyond consensus: reflections from a democratic perspective on the interaction between climate politics and science Jeroen $\mathrm{P}$ van der Sluijs ${ }^{1}$, Rinie van $\mathrm{Est}^{2}$ and Monique Riphagen ${ }^{2}$
}

\begin{abstract}
The international debate about the Intergovernmental Panel on Climate Change (IPCC) and climate science in the aftermath of 'Climategate' gives cause for reflection. While the main emphasis lies on evaluating the procedures of the IPCC during the production of the fourth assessment report, too little attention has been paid to the political role of the IPCC. This article reflects on that political role by distinguishing three strategies to deal with scientific uncertainties in interfacing science and policy: 1) quantify uncertainty, 2) building scientific consensus, and 3) openness about ignorance. Each strategy has strengths and weaknesses. The way the international community has set up the IPCC and its procedures has basically been guided by the consensus approach. The current emphasis on restoring faith in the IPCC by improving its procedures reinforces this strategy. Guaranteeing the scientific reliability of IPCC reports is indeed essential but it does not address the main weakness of the consensus approach: the underexposure of both scientific and political dissent. As a result of this weakness climate science has become politicized over the past decades. Moreover, as we illustrate for the Netherlands, the consensus approach has hindered a fullblown political climate debate. The third policy strategy that aims for more openness and attention for diversity and deep uncertainty in knowledge and views may inspire more democratic ways to organize the interface between climate politics and science.
\end{abstract}

\begin{abstract}
Addresses
${ }^{1}$ Science Technology and Society, Copernicus Institute, Utrecht University, Heidelberglaan 2, 3584 CS Utrecht, The Netherlands

${ }^{2}$ Rathenau Instituut, The Hague, The Netherlands
\end{abstract}

Corresponding author: van der Sluijs, Jeroen P (j.p.vandersluijs@uu.nl)

Current Opinion in Environmental Sustainability 2010, 2:409-415

This review comes from the Open issue

Edited by Rik Leemans and Anand Patwardhan

Received 23 July 2010; Accepted 7 October 2010

Available online 30th October 2010

$1877-3435 / \$$ - see front matter

(C) 2010 Elsevier B.V. All rights reserved.

DOI 10.1016/j.cosust.2010.10.003

\section{Introduction}

The issue of anthropogenic climate change is surrounded by much public, political, and scientific debate. The laborious climate negotiations at COP15 in Copenhagen 2009 attest to this [1]. The emails hacked and made public (known in the media as 'Climategate') right before that climate summit and the unearthing of (alleged) faults in the fourth assessment report (AR4) [2-4] early 2010 have triggered vehement debate in science and society $\left[5,6,7^{\bullet}, 8,9^{\bullet}\right]$. Questions have emerged with regard to the scientific quality and independence of the IPCC and the adequateness of the peer review process. Scientific institutions responded with independent evaluations of the contents of the hacked e-mails [10,11]. IPCC asked the InterAcademy Council (IAC) to evaluate their procedures. IAC's main advice is that IPCC should improve its communication and crisis management and should fundamentally reform its management structure and strengthen its procedures to better meet the challenges of increasingly complex climate assessments in a context of more intense public scrutiny of the scientific justifications for climate policies [12]. The political arena responded by demanding evaluation of the IPCG procedures during the production of AR4 $\left[13,14^{\bullet \bullet}\right]$. From a policy perspective, guaranteeing the scientific reliability of the IPCC report is indeed extremely important. However, to adequately respond to the present 'crisis' broader societal reflection on - and reform of - the political role of the IPCC is also urgently needed.

To this end, this paper explores the complex interaction between climate politics and science $\left[15^{\bullet \bullet}, 16^{\bullet}, 17^{\bullet \bullet}, 18^{\bullet \bullet}\right]$. For our analysis we introduce three strategies to deal with scientific uncertainties and organize the relationship between politics and science. Next, we use this typology to interpret the role IPCC plays in the science-policy interface. We discuss the key function of IPCC as producer of 'certified' scientific and policy-oriented knowledge in motivating and legitimizing (inter)national climate policy. We assess strengths and weaknesses of the current way in which the IPCC deals with a diversity of voices and uncertainties within climate science, and how these are presented to (policy makers in) the outside world. We exemplify our diagnosis of problems in the present practice of interfacing climate science and climate policy using the case of the Netherlands. Finally, we look for ways to improve the interface between climate science and policy.

\section{Three strategies to deal with scientific uncertainties in the science-policy interface}

When the science-policy interface is confronted with complex issues that are characterized by many scientific uncertainties three coping strategies may be distinguished $\left[19,20^{\bullet}, 21^{\bullet}\right]$. These strategies have their origin in the (implicit) model of interfacing science and policy 
assumed by those who perform the interfacing activities $\left[22,20^{\circ}\right]$. Note that the underlying models are exclusive but the practical strategies for managing uncertainties are not mutually exclusive, indeed the strategies are strongly complementary within the successive models.

\section{Interfacing strategy 1: quantify uncertainties}

In the 'Linear Model' of interfacing science and policy [22], ${ }^{1}$ science informs policy by producing objective, valid, and reliable knowledge. To develop a policy is then a matter of scientists delivering the facts and then, in a second step, policy makers sorting out diverse values and preferences. In classical terms, the true entails the good; in modern terms, truth speaks to power. This interfacing model implicitly assumes that scientific facts linearly determine correct policy: good governance is getting the facts right and calculate the optimal policy. The belief is that being based on scientific facts, the power that is exercised is effective, legitimate, and based on unambiguous objectivity and indisputable rationality. This approach implicitly assumes that there are no limits to the progress of man's control over his environment, no limits to the capacity of science to know and understand, and no limits to the material and moral progress of mankind. This is the classic 'technocratic' view of governance dependent on an assumed perfection/perfectibility of science in theory and also (progressively) in practice. Within this Linear Model, scientific uncertainty is seen as a temporary shortcoming in knowledge. The related interfacing strategy is to quantify and push back the uncertainty by more research, for example, creating increasingly complex climate models and through perturbed physics ensemble modelling [23,24]. Calculation is seen as key to well-informed good governance. This approach is limited by the fact that not all uncertainties can be expressed quantitatively in a reliable way. What's more, in practice uncertainties do not become reduced with more research: the problem appears to become ever more complex [ $\left.25^{\circ}\right]$. It further assumes that there is only one correct scientific description of the system that is analyzed: in other words it assumes that the system and problem are not complex. It thereby ignores that multiple - often conflicting - scientific interpretations of the same available knowledge are tenable. The drawback of this approach is that there is a semblance of certainty, for example, because the numbers coming from the increasingly complex models suggest that there is more knowledge and more certainty than is actually the case.

\section{Interfacing strategy 2: build scientific consensus}

In response to the phenomenon that science does not speak with one voice to policy but tends to speak many, often conflicting truths, to power, the emergence of a Consensus Model can be observed in an attempt to

\footnotetext{
${ }^{1}$ Note that Funtowicz [22] uses the term 'Modern Model', referring to the modern tradition of European Enlightenment.
}

'rescue' the Linear Model from conflicting certainties and multiple framings. Within this interfacing model uncertainty is primarily perceived as a problematic lack of unequivocalness. One scientist says this, the other says that. It is unclear who is right and which scientific viewpoint should guide the decision making. The solution has been a comparative and independent evaluation of research results, aimed at building scientific consensus via multidisciplinary expert panels. This approach is geared towards generating robust findings representing 'the best of our knowledge' that is used as a proxy for the scientific truth that is needed in the Linear Model. The drawbacks of this approach are that it leads to anchoring towards previously established consensus positions [26], it hides diversity of perspectives thereby unduly constraining decision-makers options [27], it underexposes issues over which there is no consensus whereas it is precisely this dissent that tends to be extremely relevant to policymaking [19].

\section{Interfacing strategy 3: openness about ignorance}

In the Consensus Model, the core activity of the Linear Model, the experts' (desire for) truth speaking to the politicians' (need for) power, is left unquestioned and unchanged. Confronted with complex issues with high decision stakes, uncertain facts and values in dispute, scientists may still aim to deliver truth, but often there are many competing interpretations of the same problem (conflicting truths), none of which can be refuted given the state of knowledge-so that a consensus can only be an enforced reduction of complexity into single 'best of our knowledge' claim. In case of such complex issues, both the Linear Model and the Consensus Model are not fit for the characteristics of the issue addressed, because the truth cannot be known at the moment the decision needs to be made, and can thus not be a substantial aspect of the issue. As Funtowicz and Ravetz [28] phrased it: "To be sure, good scientific work has a product, which should be intended by its makers to correspond to Nature as closely as possible, and also to be public knowledge. But the working judgements on the product are of its quality, and not of its logical truth." Building on these notions, an alternative model of science and policy has been proposed: the Deliberative Model, in which the appreciation of a plurality of (often irreconcilable) perspectives is key. Within this interfacing model uncertainty is seen as something that unavoidably plays a permanent role in complex and politically sensitive topics. This approach $\left[29^{\bullet \bullet}, 20^{\bullet}, 30^{\bullet}\right]$ recognizes that ignorance (lack of understanding of the complex climate system) and values play a central role. The search is for a robust policy, which is useful regardless of which of the diverging scientific interpretations of the knowledge is correct. The drawback of this approach is that uncertainty and minority interpretations are so much in the spotlight that we may forget the items that actually do enjoy broad scientific consensus (see $\left[31,32,33^{\bullet \bullet}, 34^{\bullet \bullet}\right]$ for accounts of the present scientific 
Table 1

Overview of strengths and weaknesses of three policy strategies to deal with scientific uncertainties (modified from [19])

\begin{tabular}{lllll}
\hline & Scientific uncertainty as ... & \multicolumn{1}{c}{ Interfacing strategy } & \multicolumn{1}{c}{ Strength } & Weakness \\
\hline 1 & Lack of precision & Quantify uncertainty & Searching for scientific certainties & Creating illusionary certainty \\
2 & Lack of unequivocalness & Build scientific consensus & Exposing consensus & Underexposing dissent \\
3 & Fact of life & Openness about ignorance & Exposing dissent & Underexposing consensus \\
\hline
\end{tabular}

consensus and $\left[35^{\bullet}, 36^{\bullet}, 37^{\bullet}, 38,39^{\bullet}, 40\right]$ for reviews of the state of knowledge).

Table 1 summarizes the strengths and weaknesses of these strategies.

\section{Strength of the IPCC consensus approach}

The way in which international politics framed the IPCC when it was established in 1988 was mainly guided by the second policy strategy of coping with scientific uncertainties. To guarantee the policy relevance of the IPCC, politicians at that time opted for a consensus approach when dealing with scientific uncertainties. ${ }^{2}$ In that period many contradictory studies about causes, effects, and seriousness of the climate change problem existed. Policymakers realized that they needed a clear policyoriented knowledge base, on which international climate policy could be based. To achieve that the IPCC was set up as an independent yet intergovernmental scientific panel by the United Nations Environment Programme (UNEP) together with the World Meteorological Organization (WMO) [41]. IPCC reports aim to identify the state of (chiefly peer-reviewed) knowledge while enjoying wide scientific support. This goal fosters developing consensus in the editorial teams. By mapping out scientific consensus, the IPCC fulfills a central political function in certifying robust knowledge that can serve as a foundation for climate policy.

Every 5 or 6 years the IPCC publishes a multi-volume assessment report presenting an overview of the state of knowledge. These reports consist of three partial reports. Partial report I covers the physical science basis (climate system and causes), report II discusses impacts, adaptation, and vulnerability, and report III looks at mitigation (possibilities to tackle the causes). Each volume has a summary for policymakers, while a synthesis report summarizes the findings of the whole report. Participating governments and scientists together determine the content of the policy summaries. Governments formally accept the reports of the IPCC. This procedure ensures that these reports can also count on wide support from

\footnotetext{
${ }^{2}$ The recent IPCC reports also contain elements from the first and third approaches. In addition to reporting of quantified uncertainty ranges (approach 1) we increasingly find qualitative indications of the level of scientific understanding for several of the figures (approach 3), see also [60].
}

governments and policymakers and are considered as an authoritative source [42].

From the start, the work of IPCC has been strongly framed by its political context. Its first assessment report (1990 [43]) served as the scientific basis under the UN Framework Convention on Climate Change (UNFCCC) that was signed in 1992. This put climate policy high on the national and international agenda. The main goal of UNFCCG - established in article 2 - is to stabilize concentrations of greenhouse gasses in the atmosphere at a level that prevents dangerous anthropogenic interference with the climate system. This level must be reached within such a sufficient time frame that ecosystems are allowed to adapt naturally to climate change, the food production is not threatened, and the economy can develop in a sustainable manner (in other words: a balance should be found between the damage to ecology and food production if emission reduction is too slow and the disruption of socio-economic development by the high costs of reducing emissions too fast).

The current tendency in the aftermath of 'climate gate' and the unearthing of faults in AR4 is to improve IPCC procedures via external evaluations. This reinforces the consensus approach: people are looking for ways to continue with the existing practices and legitimize them politically. Although such a process is important, it is even more important to respond to the weaknesses of the consensus approach. In the following sections we reflect on its instrumental weaknesses and fundamental flaws.

\section{Instrumental weakness of the IPCC consensus approach}

The consensus approach deprives policy makers of a full view of the plurality of scientific opinions within and between the various scientific disciplines that study the climate problem. Partly, this results from the way in which scientific uncertainties are momentarily communicated. The IPCC's own guideline prescribes that any diverging scientific visions on certain aspects should be reported in the chapters that discuss those aspects. As far as we can oversee it, this does get done. Yet policymakers' summaries and synthesis reports do not provide insights into where in science is there dissent. Examples of such dissent are disputes over the role of man compared to the role of the sun in the observed and projected climate trends, the hockey stick controversy, contradicting recon- 
structions of $\mathrm{CO}_{2}$ concentrations in the past, and the keyassumption that climate sensitivity is constant over time $\left[14^{\bullet \bullet}\right]$. To get a good picture of the various unresolved scientific disputes one has to read the entire AR4. The current IPCC consensus model also causes weak signals from the scientific community of potentially large impacts to get a less prominent spot in the reports than they may deserve based on their policy relevance (see also $\left[20^{\circ}\right]$ ). This is the case with tipping points [ $\left[44^{\circ}\right]$ : they can lead to severe non-linear impacts, but given the state of knowledge and the many uncertainties, univocal scientific consensus about the severity and scope of many of these tipping points cannot yet be reached. Still, such dissent is policy-relevant: when designing a policy strategy you better have thought beforehand about extreme scenarios that cannot be ruled out but have an unknown chance of happening than be completely surprised if they occur unexpectedly at a later time while early warnings from dissenting scientists were not heard (see also $\left[45^{\circ}\right]$ ).

\section{Fundamental weakness of the IPCC consensus model: the case of the Netherlands [14"•]}

To exemplify our diagnosis of the more fundamental problems in the present practice of interfacing climate science and climate policy, we briefly elaborate the case of the Netherlands. For the Netherlands, the linear consensus model has 'worked' for a long time: it provided a long-lasting broad political consensus about climate policy. On the negative side, the focus on consensus hindered a full-blown political climate debate that in turn has politicized climate science. Paradoxically, the consensus approach was originally chosen in the hope that it would have depoliticized the science, but instead it created vulnerabilities in the science policy interface (such as the tendency of overselling certainty) that can easily be exploited.

Analysis of parliamentary debates over the past twenty years $\left[14^{\bullet \bullet}\right]$ shows that IPCC reports are continuously used to keep the political debate within bounds. Questions have repeatedly been asked in the Dutch Parliament about scientific information and scientific uncertainties surrounding the climate issue. These questions come from the entire political spectrum. The government consistently answers that scientific uncertainties do exist, but that policies are based on the IPCC reports and the precautionary principle. Because the political arena has given the IPCC reports such a central role, the political conflict about climate change and the underlying ideological contradictions have penetrated deep into the field of climate science. In other words, political influence nowadays can be achieved most effectively via climate science. With the IPCC reports in hand, proponents of the climate debate claim a preferential position in the debate. Opponents try to reopen the political debate by magnifying uncertainties and imperfections in climate science [46-49].
In the post-Climategate discussion the linear model has been harshly attacked, yet also strongly defended and upheld $\left[14^{\bullet \bullet}\right]$. To clean up the blemished blazon of the IPCC - that is, to restore the linear interaction model between climate politics and science - the Dutch government defended the linear model and ordered an independent evaluation of errors in AR4 [13].In the United States where until recently the political climate debate was completely stuck the linear model has never worked [50]. More climate research and the consensus reports of the IPCC did not lead to less political conflict there. In the Netherlands the linear model has induced a scientification of the political climate debate because politics are dependent on scientific knowledge. In turn, science ends up at the heart of the political conflict, and when the stakes get high in political decisions, the scientific debate becomes politicized [51-54]. As a result, those who have vested interests regarding what is at stake deliberately start to deploy certain tactics to turn scientific results in their favor, to bring a favorable study to the fore, or to be rid of inconvenient knowledge [55-57,58*0 $]^{3}$.

Since the early 1990s, the IPCC has played a central political role in the countries that implemented climate policies under the UNFCCG. The scientific knowledge gathered and processed by the IPCC legitimizes domestic and international policy aimed at reducing greenhousegas emissions. Moreover, the long-term policy goals of the Framework Convention have become leading for the financing, organization and any questions surrounding a large portion of climate science, in particular in the domains of climate mitigation, climate adaptation, and carbon sinks.

It is because of the central political role of the IPCC that precisely around the climate summit in Copenhagen (COP 15) the scientific debate flared up and became polarized. This political key role of science is the most important moving force behind politicization of policyoriented climate science. This partly explains why faults in a three-year-old scientific report (i.e. 'Himalaya gate' in AR4) are front-page news these days.

\section{Epilogue: towards a more democratic perspective}

Given the intense criticism, repairing the Linear Model by evaluating the IPCC is a logical and good step to take. A good picture of the status of climate science is in fact an important precondition for prudent domestic and international climate policies.

Still, more is needed. To move beyond consensus the deliberative model offers a promising complementary

\footnotetext{
${ }^{3}$ Note that the fact that the references here discuss corporate strategies, does not mean that NGO's do not deploy these strategies too. It seems just less well documented in the literature.
} 
approach to interface climate science and policy, based on openness about uncertainty and ignorance, systematic reflection, and argued choice. This remedies the basic weakness of the Linear Model that underexposes the scientific as well as the political dissent. It can fruitfully broaden the option space for decision making and enhance societies' capacity to deal with uncertainties surrounding knowledge production and knowledge use in the management of climate risks. To this end, both the scientific and the political climate debate need more space and attention for diversity and uncertainty in knowledge and views. Consequently, it is necessary to make climate science less political. This can be accomplished by offering room for dissent within climate science and communicating about it with policymakers. It should also be acknowledged that climate policies can be justified in moral terms without any need for recourse to abstract climate or economic models [59 $\left.{ }^{\bullet}\right]$. An excessive mutual dependence between science and policy should also be prevented. The political climate debate would benefit from clarification of the political values and visions that are at play in climate change. The climate debate could be expanded by paying attention to socially attractive development perspectives. The growing focus on climate adaptation also has the power to highlight and expand the political climate debate.

\section{References and recommended reading}

Papers of particular interest, published within the annual period of review, have been highlighted as:

- of special interest

$\bullet$ of outstanding interest

1. Tollefson J: World looks ahead post-Copenhagen. Nature 2009, 462:966-967.

2. IPCC: Climate Change 2007: The Physical Science Basis Cambridge: Cambridge University Press; 2007.

3. IPCC: Climate Change 2007. Impacts, Adaptation and Vulnerability. Cambridge: Cambridge University Press; 2007.

4. IPCC: Climate Change 2007. Mitigation of Climate Change. Cambridge: Cambridge University Press; 2007.

5. Heffernan O: Climate data spat intensifies. Nature 2009, 460:787 doi: $10.1038 / 460787$.

6. Schiermeier Q: IPCC flooded by criticism. Nature 2010, 463:596597 doi: 10.1038/463596a.

7. Schiermeier Q: The real holes in climate science. Nature 2010 , - 463:284-287 doi: $10.1038 / 463284 a$.

Brief overview of key gaps in our understanding of the climate system.

8. Kitcher P: The Climate Change Debates. Science 2010, 328:1230-1234 doi: 10.1126/science.1189312.

9. Prins G, Galiana I, Green C, Grundmann R, Hulme M, Korhola A

- Laird F, Nordhaus T, Pielke Jr R, Rayner S, Sarewitz D, Shellenberger M, Stehr N, Tezuka H: The Hartwell Paper A new direction for climate policy after the crash of 2009. http:// eprints.Ise.ac.uk/27939/; 2010.

Plea for reframing international climate policy in terms of three human dignity-related objectives: ensuring energy access for all; ensuring that development does not undermine the essential functioning of the Earth system; ensuring that societies are adequately equipped to withstand man made and natural climate changes.
10. Foley HC, Scaroni AW, Yekel CA: Inquiry Report Concerning the Allegations of Research Misconduct Against Dr. Michael E. Mann, Department of Meteorology, College of Earth and Mineral Sciences. The Pennsylvania State University. http:// www.research.psu.edu/orp/Findings_Mann_Inquiry.pdf; 2010.

11. Russel M, Boulton G, Clarke P, Eyton, D, Norton J: The Independent Climate Change E-mails Review. http://www.cce-review.org; 2010.

12. InterAcademy Council Committee to Review the IPCC: Climate Change Assessments Review of the Processes and Procedures of the IPCC. Amsterdam: InterAcademy Council. http:// reviewipcc.interacademycouncil.net/report.html; 2010.

13. Meyer LA, Petersen AC (Eds): Assessing an IPCC assessment An analysis of statements on projected regional impacts in the 2007 report. Bilthoven: Netherlands Environmental Assessment Agency http://www.pbl.nl/images/500216002_tcm61-48119.pdf; 2010.

14. Van der Sluijs JP, Van Est R, Riphagen M (Eds): Room for Climate -. Debate: Perspectives on the Interaction Between Climate Politics, Science and the Media. The Hague: Rathenau Instituut; 2010.

The study offers an insightful analysis of the complex interaction between climate politics, science and the media and the politicization of climate science over the past decades.

15. Bolin B: A History of the Science and Politics of Climate Change

-. The Role of the Intergovernmental Panel on Climate Change. Cambridge: Cambridge University Press; 2007.

Must-read insider perspective on the history of the IPCC.

16. Hulme M: Why We Disagree About Climate Change,

- Understanding Controversy, Inaction and Opportunity. Cambridge: Cambridge University Press; 2010.

Diagnosis of the many different levels at which disagreement arises and its relation to political stances and value orientations that are at the root of controversies on climate science and climate policy.

17. Edwards P: A Vast Machine, Computer Models, Climate Data and -• the Politics of Global Warming. Cambridge: MIT Press; 2010. Must-read book on the roles of models and data in climate science from a history of science perspective.

18. Pereira Guimaraes Â, Funtowicz S: Science for Policy. Oxford: •. Oxford University Press; 2009.

State of the art overview of science for policy from a post-normal science perspective.

19. Van der Sluijs JP: Uncertainty, assumptions, and value commitments in the knowledge-base of complex environmental problems. In Interfaces between Science and Society. Edited by Guimarães Pereira Âcr;, Guedes Vaz S, Tognetti S. Sheffield: Green Leaf Publishing; 2006:67-84.

20. Van der Sluijs JP: Uncertainty and complexity: the need for new - ways of interfacing climate science and climate policy. In From Climate Change to Social Change: Perspectives on SciencePolicy Interactions. Edited by Driessen P, Leroy P, Van Vierssen W:. Utrecht: International Books; 2010:31-49.

Provides a diagnosis of the problems of the linear model, discusses the various attempts to repair it and presents a science-policy model of openness about uncertainty and extendend participation as alternative.

21. Petersen AC, Hage M, Cath A, Van der Sluijs JP: Post-Normal

- Science in Practice at the Netherlands Environmental Assessment Agency. Science Technology \& Human Values; in press, doi:10.1177/0162243910385797.

Insider account of a transition of a science policy institute towards a postnormal science approach to interfacing science and policy.

22. Funtowicz SO: Why knowledge assessment? In Interfaces between Science and Society. Edited by Guimarães Pereira Âcr;, Guedes Vaz S, Tognetti S. Sheffield: Green Leaf Publishing; 2006: 138-145.

23. Murphy JM, Sexton DMH, Barnett DN, Jones GS, Webb MJ, Collins M, Stainforth DA: Quantification of modelling uncertainties in a large ensemble of climate change simulations. Nature 2004, 430:768-772 doi: 10.1038/ nature02771.

24. Knutti R, Joos F, Muller SA, Plattner G-P, Stocker TF: Probabilistic climate change projections for $\mathrm{CO}_{2}$ stabilization profiles. Geophysical Research Letters 2005, 32:L20707 doi: 10.1029/2005GL023294. 
25. Trenberth K: More knowledge, less certainty. Nature Reports - Climate Change 2010, 4:20-21.

Explains and discusses the paradox that more climate research does not reduce uncertainty about future climate changes.

26. Van der Sluijs JP, Van Eijndhoven JCM, Wynne B, Shackley S: Anchoring devices in science for policy: the case of consensus around climate sensitivity. Social Studies of Science 1998, 28:291-323 doi: 10.1177/030631298028002004.

27. Pielke R Jr: Room for Doubt. Nature 2010, 410:151 doi: 10.1038/ 35065759.

28. Funtowicz SO, Ravetz JR: Uncertainty and Quality in Science for Policy. Dordrecht: Kluwer; 2010.

29. Van der Sluijs JP, Petersen AC, Janssen PHM, Risbey JS,

- Ravetz JR: Exploring the quality of evidence for complex and contested policy decisions. Environmental Research Letters 2008, 3:024008 doi: 10.1088/1748-9326/3/2/024008.

Presents a state-of-the-art reflective approach to assessing and communicating uncertainty in science for policy, whereby key quality aspects of knowledge production and use are addressed through a knowledge quality assessment checklist.

30. Brown JD: Prospects for the open treatment of uncertainty in - environmental research. Progress in Physical Geography 2010, 34:75-100 doi: 10.1177/0309133309357000.

Analysis of three myths about the consequences and causes of imperfect knowledge that dominate present day uncertainty treatment: (1) the dominance of system complexity, non-linearity and space-time variability, over social and psychological factors; (2) the primacy of observations in locating, quantifying, and reducing uncertainty; and (3) the value of technical assessments of uncertainty in 'risk-based decision-making'. Prospects for the open treatment of uncertainty are discussed in terms of circumventing the three myths.

31. Oreskes N: Beyond the ivory tower: The scientific consensus on climate change. Science 2004, 306:1686-11686 doi: 10.1126/ science. 1103618 .

32. Pielke RA Jr: Consensus about climate change? Science 2005 , 308:952-953 doi: 10.1126/science.308.5724.952.

33. Doran PT, Kendall Zimmerman M: Examining the scientific - consensus on climate change. EOS 2009, 90:22-23.

Empirical account of the degree of consensus in the scientific community on anthropogenic climate change.

34. Pirtle Z, Meyer R, Hamilton A: What does it mean when climate

$\bullet \quad$ models agree? A case for assessing independence among general circulation models. Environmental Science \& Policy 2010, 13:351-361 doi: 10.1016/j.envsci.2010.04.004.

GCMs are independent of, and interdependent on one another, in different ways and degrees. This paper addressing the issue of model independence in the light of the question whether agreement between models should boost confidence that their results have basis in reality.

35. Bony S, Colman R, Kattsov VM, Allan RP, Bretherton CS,

- Dufresne J-L, Hall A, Hallegatte S, Holland MM, Ingram W et al. How well do we understand and evaluate climate change feedback processes? Journal of Climate 2006, 19:3445-3482.

Review of state of knowledge on climate change feedbacks and their inclusion in GCM models.

36. NAS: Surface Temperature Reconstructions for the Last 2,000

- Years. Report of the Committee on Surface Temperature Reconstructions for the Last 2,000 Years. National Research Council, National Academy of Sciences. Washington: The National Academy Press, http://www.nap.edu/ catalog.php?record id=11676; 2006.

Independent review of the Hockey stick controversy.

37. Bader DC, Covey C, Gutkowski Jr WJ, Held IM, Kunkel KE, Miller

- RL, Tokmakian RT, Zhang MH: Climate Models: An Assessment of Strengths and Limitations. Washington: US Department of Energy. http://pubs.giss.nasa.gov/docs/2008/2008 Bader etal.pdf; 2008.

Very good overview of strengths and limitations of present day climate models.

38. Smith JB, Schneider SH, Oppenheimer M, Yohe GW, Hare W, Mastrandrea MD, Patwardhan A, Burton I, Corfee-Morlot JC Magadza CHD et al.: Assessing dangerous climate change through an update of the Intergovernmental Panel on Climate
Change (IPCC) “'reasons for concern”. PNAS 2006, 106:41334137 doi: 10.1073/pnas.0812355106.

39. Füssel H-M: An updated assessment of the risks from climate - change based on research published since the IPCC Fourth Assessment Report. Climatic Change 2009, 97:469-482 doi: 10.1007/s10584-009-9648-5.

Nice review of new insights on anthropogenic climate change published since the AR4.

40. Richardson K, Steffen W, Schellnhuber HJ, Alcamo J, Barker T, Kammen DM, Leemans R, Liverman D, Munasinghe M, OsmanElasha B, Stern N, et al:: Synthesis report Climate Change Global Risks, challenges \& decisions. Copenhagen: University of Copenhangen. http://climatecongress.ku.dk/pdf/synthesisreport; 2009.

41. Agrawala S: Structural and process history of the intergovernmental panel on climate change. Climatic Change 1998, 39:621-642 doi: 10.1023/A:1005312331477.

42. Petersen AC: Simulating nature: a philosophical study of computer-simulation uncertainties and their role in climate science and policy advice. Apeldoorn \& Antwerp: Spinhuis Publishers. http://hdl.handle.net/1871/11385; 2006.

43. IPCC: Climate Change: Scientific Assessment Cambridge: Cambridge University Press; 1990.

44. Lenton TM, Held H, Kriegler E, Hall JW, Lucht W, Rahmstorf S,

- $\quad$ Schellnhuber HJ: Tipping elements in the Earth's climate system. PNAS 2008, 105:1786-1793 doi: 10.1073/ pnas.0705414105.

Expert jugements on thresholds and imminence of a wide range of tipping points in the climate system.

45. EEA: Late Lessons from Early Warnings. The precautionary

- principle 1896-2000. Copenhagen: European Environment Agency. http://www.eea.europa.eu/publications/ environmental issue report 2001 22; 2001.

Must-read report analyzing 14 historic case studies where early warning signals from science where not timely followed up by policy action, which subsequently lead to disasters. Presents 12 lessons for future precautionary policy making. Be sure to look out for the forthcoming volume II of the late lessons report, presenting many new cases studies and new lessons, which will be published by the EEA in 2011.

46. Mccright AM, Dunlap RE: Defeating Kyoto: the conservative movement's impact on U.S., climate change policy. Social Problems 2003, 50:348-373 doi: 10.1525/sp.2003.50.3.348.

47. McKitrick R (Ed): Independent Summary for Policymakers. IPCC Fourth Assessment Report. Vancouver: Fraser Institute. http:// www.uoguelph.ca/ rmckitri/research/ispm.html; 2007.

48. Singer SF (Ed.): Nature, Not Human Activity, Rules the Climate: Summary for Policymakers of the Report of the Nongovernmental International Panel on Climate Change. Chicago: The Heartland Institute. http://www.heartland.org/custom/semod_policybot/pdf/ 22835.pdf; 2008.

49. Idso C, Singer SF (Eds): Climate Change Reconsidered. Chicago: Heartland Institute http://www heartland org/publications/ NIPCC\%20report/PDFs/NIPCC\%20Final.pdf; 2009.

50. Sarewitz D, Pielke RA: Breaking the global-warming gridlock. The Atlantic Monthly July 2000, 286:54-64.

51. Jasanoff S, Markle GE, Petersen LC, Pinch TJ: Handbook of Science and Technology Studies. Thousand Oaks: Sage; 1995.

52. Jasanoff S, Wynne B: Science and decision making. In Human Choice and Climate Change, vol. 1, The Societal Framework. Edited by Rayner S, Malone EL. Columbus: Battelle Press; 1998:1-87.

53. Irwin A: Sociology and the Environment. Cambridge: Polity Press; 2001.

54. Sarewitz D: How science makes environmental controversies worse. Environmental Science and Policy 2004, 7(5):385-403.

55. Michaels D: Doubt is their product. Industry groups are fighting government regulation by fomenting scientific uncertainty. Scientific American 2005, 292:96-101.

56. Gleick P: Testimony to the Senate Committee on Commerce, Science, and Transportation for the Hearing on Climate Change 
Research and Scientific Integrity February 7, 2007 Threats to the Integrity of Science. Oakland: Pacific Institute. http://www.pacinst. org/publications/testimony/Gleick_Senate_Commerce_2-7-07. pdf; 2007.

57. Hoggan J: Climate Cover-up: The Crusade to Deny Global Warming Vancouver: Greystone books; 2009.

58. Oreskes N, Conway E: Merchants of Doubt, How a Handful of

-. Scientists Obscured the Truth on Issues from Tobacco Smoke to Global Warming. New York: Bloomsbury Press; 2010.

Illuminating analysis of strategies of industrial lobby groups to discredit unwelcome knowledge and manufacture doubt and scientific uncertainty to safeguard profit and vested interests. Also check out ref 56 above which adds an insightful typology that helps naming and recognizing these deceitful tactics.

59. Rommetveit K, Funtowicz S, Strand A: Knowledge, democracy

- and action in response to climate change. In

Interdisciplinarity and Climate Change Transforming Knowledge and Practice for our Global Future. Edited by Bhaskar R, Frank C, Hoyer KG, Naess P, Parker J. London: Taylor \& Francis; 2010: 149-163.

60. Swart R, Bernstein L, Ha-Duong M, Petersen A: Agreeing to disagree: uncertainty management in assessing climate change, impacts and responses by the IPCC. Climatic Change 2009, 92:1-29 doi: 10.1007/s10584-008-9444-7. 